\title{
PENGARUH MODEL PEMBELAJARAN INKUIRI TERBIMBING TERHADAP KETERAMPILAN PROSES DAN PENGUASAAN KONSEP SAINS DITINJAU DARI PENGETAHUAN AWAL PESERTA DIDIK
}

\author{
Mohammad Wawan Fatwa*, Ahmad Harjono ${ }^{2}$ Jamaluddin $^{2}$ \\ ${ }^{1}$ Sekolah Menengah Atas Negeri 7 Mataram \\ ${ }^{2}$ Program Magister Pendidikan IPA, Universitas Mataram \\ *Email: wawanfatwa26@gmail.com
}

\begin{abstract}
The study intended to discover : 1) the impact of Guided Inquiry Learning Model (henceforth, GILM) towards students scientific processing skills and conceptual mastery which was reviewed from their prior knowleadge (high or low ), 2) the impact of students basic level of knowledge towards their scientific processing skills and conceptual mastery, and 3) the interaction between learning model and students prior knowledge towards their scientific processing skills and conceptual mastery. The study employed quasi experimental method with $2 \times 2$ factorial analyses. The study was conducted in Junior High School 2 Mataram (SMPN 2 Mataram) in academic year of 2016/2017. The sample of data collection utilized cluster random sampling technique. Both experimental and control groups were consisted of 62 students. Scientific processing skills and conceptual mastery observation sheets were used as research instruments. The data analyzed with Anava with SPSS version 20 for windows. The results showed that 1) there was a significant impact of GILM and conventional learning model towards students' scientific processing skills and conceptual mastery, 2) there was no significant impact of students prior knowledge towards their scientific processing skills and conceptual mastery, 3) there was no interaction between learning models and students' prior knowledge towards their scientific processing skills and conceptual mastery.
\end{abstract}

Keywords: Guided Inquiry Learning Model, Prior Knowledge, Science Process Skills, and Science concept mastery

\section{PENDAHULUAN}

Ilmu Pengetahuan Alam

berkaitan dengan cara mencari tahu tentang alam secara sistematis, sehingga IPA bukan hanya penguasaan kumpulan pengetahuan yang berupa fakta-fakta, konsep-konsep atau prinsip-prinsip saja, tetapi juga merupakan suatu proses penemuan. Proses pembelajaran IPA menekankan pada pemberian pengalaman langsung untuk mengembangkan kompetensi agar menjelajahi dan memahami alam sekitar secara ilmiah. Pembelajaran IPA diarahkan untuk inkuiri sehingga dapat membantu peserta didik untuk memperoleh pemahaman yang lebih mendalam tentang alam sekitar (Kemendikbud, 2013).

Tujuan pembelajaran IPA dalam kurikulum 2013 diharapkan dapat menjadi wahana atau sarana untuk melatih para peserta didik agar dapat menguasai konsep dan prinsip IPA, memiliki kecakapan ilmiah, memiliki keterampilan proses sains dan keterampilan berpikir kritis dan kreatif.

Pendekatan pembelajaran IPA hendaknya berorientasi pada peserta didik (student centered). Peranan pendidik adalah memperkaya pengalaman belajar peserta didik. Pengalaman tersebut dapat diperoleh melalui serangkaian kegiatan melalui interaksi aktif dengan teman sejawat dan seluruh lingkungan belajarnya. Pembelajaran disekolah lebih dari sekedar proses membantu peserta didik untuk belajar. Dalam hal ini, guru harus yakin bahwa peserta didik benar-benar terbantu untuk mempelajari materi pelajaran dan keterampilan yang dituntut dalam kurikulum. Dalam mewujudkan hal tersebut perlu adanya suatu model pembelajaran 
inovatif yang diterapkan dalam pembelajaran IPA (Jufri, 2013).

Model pembelajaran inkuiri merupakan salah satu model pembelajaran yang mengacu pada kurikulum 2013. Menurut Arslan (2014), pembelajaran inkuiri dikembangkan untuk mengajar para peserta didik memahami proses meneliti dan menerangkan suatu kejadian. Kegiatan model pembelajaran inkuiri, peserta didik dilatih untuk melakukan suatu percobaan yang dimulai dari merumuskan masalah, mengajukan dan menguji hipotesis, menentukan variabel, merancang dan merakit instrumen, mengumpulkan, mengolah dan menafsirkan data, menarik kesimpulan serta mengkomunikasikan hasil percobaan secara lisan dan tertulis. Keterampilan-keterampilan tersebut dapat disebut juga keterampilan proses sains. Pembelajaran dengan mengembangkan keterampilan proses memudahkan peserta didik untuk menemukan suatu konsep, prinsip atau teori untuk mengembangkan konsep yang telah ada sebelumnya, ataupun untuk melakukan penyangkalan terhadap suatu penemuan (Azizirrahim, et al, 2015). Pembelajaran berbasis inkuiri yang didasarkan atas peran pendidik dan peserta didik memiliki empat tingkatan yaitu: 1) level 1(inkuiri konfirmasi), 2) level 2 (inkuiri terstruktur), 3) level 3 (inkuiri terbimbing), 4) level 4 (inkuiri terbuka) (Bell, et al, 2005). Pembelajaran inkuiri terbimbing berorientasi pada aktivitas kelas yang berpusat pada peserta didik dan memungkinkan peserta didik belajar memanfaatkan berbagai sumber belajar yang tidak hanya menjadikan pendidik sebagai sumber belajar. Peserta didik secara aktif akan terlibat dalam proses mentalnya melalui kegiatan pengamatan, pengukuran, dan pengumpulan data untuk menarik kesimpulan. Penggunaan inkuiri terbimbing disebabkan karena perkembangan intelektual peserta didik pada usia SMP menurut Piaget berada pada tingkatan operasional formal (Wood, et al, 2011). Periode ini anak telah dapat berfikir logis, berfikir dengan pemikiran teoritis formal berdasarkan proposisi dan berhipotesis. Seluruh aktivitas yang dilakukan peserta didik diarahkan untuk mencari dan menemukan jawaban sendiri dari suatu yang dipertanyakan, sehingga diharapkan dapat meningkatkan keterampilan dan penguasan konsep peserta didik (Sanjaya, 2012). Penguasaan konsep peserta didik terbentuk sebagai hasil modifikasi maupun penguatan terhadap konsep yang sudah dimiliki peserta didik (Azis, 2013).

Hal ini sesuai dengan pendapat Ambarsari (2012), yang menyimpulkan bahwa penerapan pembelajaran inkuiri terbimbing memberikan pengaruh yang siginifikan terhadap keterampilan proses sains peserta didik. Selain itu, pembelajaran inkuiri terbimbing dapat meningkatkan keterampilan proses sains peserta didik sehingga penguasaan konsep terhadap materi pembelajaran juga mengalami peningkatan. Penguasaan konsep dan keterampilan proses sains antara peserta didik yang mengikuti pembelajaran model inkuiri terbimbing lebih baik daripada peserta didik yang mengikuti model pembelajaran langsung (Tangkas, 2012).

Keberhasilan proses pembelajaran selain dipengaruhi oleh model pembelajaran juga dipengaruhi oleh faktor peserta didik. Faktor-faktor yang dapat mempengaruhi proses pembelajaran meliputi aspek latar belakang dan sifat yang dimiliki peserta didik. Sifat yang dimiliki oleh peserta didik meliputi kemampuan dasar, pengetahuan dan sikap. Faktor tunggal paling penting yang mempengaruhi pembelajaran adalah apa yang diketahui oleh peserta didik. Pengetahuan awal merupakan faktor penting bagi peserta didik dalam proses pembelajaran $(\mathrm{H}$, Yarden \& $\mathrm{A}$, Yarden, 2010). Mengungkapkan bahwa penggunaan 
pengetahuan awal dalam proses pembelajaran akan memudahkan peserta didik memahami konsep serta hubungan antar konsep (Adodo, 2013). Dalam penelitian ini, faktor peserta didik yang digunakan adalah pengetahuan awal peserta didik yang diperoleh dari hasil tes awal (pretest) dari materi cahaya dan alat-alat optik. Peserta didik memiliki pengetahuan yang berbeda yang dapat dikelompokkan pada peserta didik berpengetahuan tinggi, sedang dan rendah. Peserta didik yang memiliki pengetahuan tinggi biasanya ditunjukkan oleh motivasi yang tinggi, sebaliknya peserta didik yang tergolong pada pengetahuan rendah ditandai dengan kurangnya motivasi belajar (Sanjaya, 2012). Sejalan dengan peneitian diatas Adodo (2013), menyatakan peserta didik berpengetahuan awal tinggi cenderung lebih baik dalam mengungkapkan hasil analisis mengenai konsep fisika dalam peristiwa sehari-hari dan menerima pengetahuan baru dibandingkan peserta didik yang berpengetahuan rendah.

Jannah (2015), menyatakan pengetahuan awal peserta didik adalah sejumlah informasi yang dimiliki oleh peserta didik yang berkaitan dengan materi yang akan dipelajari peserta didik, yang dapat membantunya dalam memahami materi tersebut lebih lanjut. Pengetahuan awal sangat penting dalam kegiatan pembelajaran karena pengetahuan awal dapat berupa prasyarat untuk memilih metode atau model yang akan digunakan dalam proses kegiatan pembelajaran di kelas. Peserta didik yang belum memiliki konsep atau pengetahuan awal tentang materi yang akan dipelajari maka pendidik dapat memilih model pembelajaran yang peranan peranan masih banyak memberikan bimbingan. Sebaliknya jika peserta didik yang telah memiliki pengetahuan awal yang cukup maka pendidik dapat memilih model pembelajaran yang berorientasi pada kegiatan belajar peserta didik (Jufri, 2013).

\section{METODE PENELITIAN}

Penelitian ini diarahkan untuk mengetahui pengaruh keterampilan prosses sains dan Pengetahuan awal. Jenis penelitian adalah quasy experiment dengan menggunakan desain Pretest-post test nonequivalent control group design. Dengan rancangan analisis factorial $2 \times 2$.

Tabel 1. Rancangan Penelitian

\begin{tabular}{cccc}
\hline Kelompok & Pretes & Perlakuan & Posttes \\
\hline $\mathrm{E}$ & $\mathrm{O} 1$ & $\mathrm{X}_{1}$ & $\mathrm{O} 2$ \\
$\mathrm{~K}$ & $\mathrm{O} 3$ & - & $\mathrm{O} 4$ \\
\hline \multicolumn{4}{c}{ (Sumber: Sugiyono, 2013) }
\end{tabular}

Keterangan:

E : Kelas Eksperimen

K : Kelas Kontrol

O1 : Pretes Kelas Eksperimen

O2 : Posttes Kelas Eksperimen

O3 : Pretes Keela Kontrol

O4 : Posttes Kelas Kontrol

Kegiatan penelitian diawali dengan tes awal (pretest) baik kepada kelas eksperimen maupun pada kelas kontrol.Pada kelas eksperimen diterapkan model pembelajaran inkuiri terbimbing dan kelas kontrol dengan model pembelajaran konvensional. Setelah mendapatkan perlakuan yang berbeda, kedua kelas diberikan tes akhir (posttest) mengenai penguasaan konsep sains, dan keterampilan proses sains.

Populasi dalam penelitian ini adalah semua peserta didik kelas VIII SMP Negeri 2 Mataram Tahun Pelajaran 2016/2017 yang terdiri atas 10 kelas. Teknik pengambilan sampel pada penelitian ini menggunakan teknik cluster random sampling. Dari sepuluh kelas populasi dipilih secara acak 2 kelas sampel. Kedua kelas tersebut dipilih lagi secara acak menjadisatu kelas eksperimen dan satu menjadi kelas kontrol.

Pengumpulan data dilakukan dengan menggunakan teknik tes. Tes keterampilan 
proses sains yang digunakan untuk mengukur indikator keterampilan proses yaitu mengamati (observasi), Meramalkan (prediksi), berhipotesis, merencanakan percobaan, menggunakan alat/bahan, menerapkan konsep dan berkomunikasi (Rustaman, 2005). Tes pengetahuan awal diperoleh dari hasil tes awal (Pretest).Data pengetahuan awal peserta didik dianalisis untuk menentukan kelompok peserta didik berpengetahuan awal tinggi dan peserta didik berpengetahuan awal rendah.

Teknik analisis data dalam penelitian ini adalah Independent Sample t Test dan uji anacova dengan terlebih dahulu uji normalitas dan uji homogenitas. Uji normalitas menggunakan uji chi Khuadrat yang diolah dengan software SPSS 20 for windows. Dengan kriteria Asymp.Sig $>0,05$ atau $\left(\mathrm{X}_{\text {hitung }}^{2}<\mathrm{X}_{\text {tabel }}^{2}\right)$ data berdistibusi normal. Uji homogenitas dalam penelitian ini menggunakan uji $F$. Uji $F$ bertujuan untuk mengetahui data pada masing-masing variabel terikat memiliki varians-kovarians yang homogen atau tidak. Kriteria keputusan jika Sig $>$ 0,05atau $F_{\text {hitung }}<\mathrm{F}_{\text {tabel }}$ maka data homogen atau sebaliknya. Pengolahan data menggunakan software SPSS.

$\begin{array}{ccc}\text { Pengujian } & \begin{array}{c}\text { hipotesis } \\ \text { variabel }\end{array} & \begin{array}{r}\text { terhadap } \\ \text { terikat }\end{array}\end{array}$
menggunakan uji Anakova, dengan kriteria jika $F_{\text {hitung }}>F_{\text {tabel }} \mathrm{H}_{0}$ ditolak pada taraf signifikasi 0,05 atau sebaliknya, sedangkan untuk menguji pengaruh variabel bebas terhadap variabel terikat secara simultan digunakan uji anacovadua jalur dengan kriteria jika angka menunjukkan signifikasi (Sig) > 0,05, maka $\mathrm{H}_{0}$ diterima dan jika angka signifikasi $(\mathrm{Sig})<0,05$, maka $\mathrm{H}_{0}$ ditolak. Perhitungan menggunakan software SPSS 20 for windows.

\section{HASIL DAN PEMBAHASAN}

Data hasil penelitian yang telah didapatkan, ditunjukkan dengan tabel berikut.

Tabel 2. Deskripsi Data Keterampilan Proses dan Penguasaan KonsepSains Peserta Didik Berdasarkan Pengetahuan Awal Peserta Didik

\begin{tabular}{|c|c|c|c|c|c|c|}
\hline \multicolumn{2}{|c|}{ Model Pembelajaran } & \multirow{2}{*}{$\begin{array}{l}\mathrm{N} \\
3 \\
4\end{array}$} & \multirow{2}{*}{$\begin{array}{c}\begin{array}{c}\text { Minimu } \\
\mathrm{m}\end{array} \\
20.00\end{array}$} & \multirow{2}{*}{$\begin{array}{c}\begin{array}{c}\text { Maximu } \\
\mathrm{m}\end{array} \\
95.40\end{array}$} & \multirow{2}{*}{$\begin{array}{c}\begin{array}{c}\text { Mea } \\
\mathrm{n}\end{array} \\
64.7 \\
471\end{array}$} & \multirow{2}{*}{$\begin{array}{c}\text { Std. } \\
\begin{array}{c}\text { Deviatio } \\
\mathrm{n}\end{array} \\
\begin{array}{c}18.2186 \\
3\end{array}\end{array}$} \\
\hline $\begin{array}{c}\text { Inkuiri } \\
\text { Terbim } \\
\text { bing }\end{array}$ & $\begin{array}{l}\text { Keterampilan } \\
\text { Proses }\end{array}$ & & & & & \\
\hline & $\begin{array}{l}\text { Penguasaan } \\
\text { Konsep Sains }\end{array}$ & $\begin{array}{l}3 \\
4\end{array}$ & 48.00 & 88.00 & $\begin{array}{l}70.2 \\
353\end{array}$ & $\begin{array}{c}10.4303 \\
1\end{array}$ \\
\hline & $\begin{array}{c}\text { Valid N } \\
\text { (listwise) }\end{array}$ & $\begin{array}{l}3 \\
4\end{array}$ & & & & \\
\hline \multirow[t]{3}{*}{$\begin{array}{l}\text { Konven } \\
\text { sional }\end{array}$} & $\begin{array}{l}\text { Keterampilan } \\
\text { Proses }\end{array}$ & $\begin{array}{l}2 \\
8\end{array}$ & 7.00 & 80.60 & $\begin{array}{l}53.9 \\
000\end{array}$ & $\begin{array}{c}19.9940 \\
4\end{array}$ \\
\hline & $\begin{array}{l}\text { Penguasaan } \\
\text { Konsep Sains }\end{array}$ & $\begin{array}{l}2 \\
8\end{array}$ & 48.00 & 84.00 & $\begin{array}{c}64.4 \\
286\end{array}$ & $\begin{array}{c}11.2790 \\
5\end{array}$ \\
\hline & $\begin{array}{l}\text { Valid N } \\
\text { (listwise) }\end{array}$ & $\begin{array}{l}2 \\
8\end{array}$ & & & & \\
\hline
\end{tabular}

Data deskripsi keterampilan proses sains dan penguasaan konsep sains kelas eksperimen dan kelas kontrol berdasarkan model pembelajaran dapat di tampilkan dalam bentuk gambar.

Gambar 1 memperlihatkan nilai ratarata penguasaan konsep sains peserta didik yang menggunakan model pembelajaran inkuiri terbimbing lebih tinggi dari peserta didik yang menggunakan model pembelajaran konvensional.

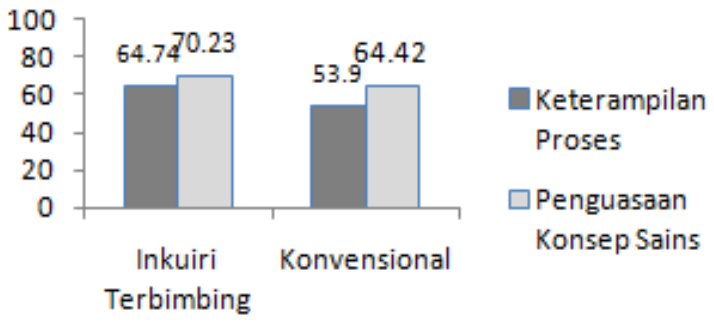

Gambar 1. Aspek keterampilan proses dan penguasaan konsep sains berdasarkan model pembelajaran

Variabel keterampilan proses sains peserta didik yang menggunakan model pembelajaran inkuiri lebih tinggi daripada model peserta didik yang menggunakan model pembelajaran konvensional 
Tabel 2. Deskripsi Data Keterampilan Proses Sains Peserta Didik berdasarkan Pengetahuan Awal Peserta Didik

\begin{tabular}{lcccc}
\hline \multirow{2}{*}{ Sumber Data } & \multicolumn{2}{c}{ Eksperimen } & \multicolumn{2}{c}{ Kontrol } \\
\cline { 2 - 5 } & Tinggi & Rendah & Tinggi & Rendah \\
\cline { 2 - 5 } & Mean & Mean & Mean & Mean \\
\hline Mengamati & 65,88 & 68,82 & 51,54 & 62,44 \\
\hline $\begin{array}{l}\text { Mengajukan } \\
\text { Pertanyaan }\end{array}$ & 59,22 & 59,41 & 42,82 & 53,11 \\
\hline $\begin{array}{l}\text { Merencanakan } \\
\text { Percobaan }\end{array}$ & 64,71 & 67,84 & 49,74 & 62,00 \\
\hline $\begin{array}{l}\text { Menggunakan } \\
\text { alat/bahan } \\
\text { percobaan }\end{array}$ & 65,69 & 67,06 & 50,00 & 62,89 \\
\hline $\begin{array}{l}\text { Mengkomunikas } \\
\text { ikan }\end{array}$ & 62,75 & 62,94 & 45,90 & 54,67 \\
\hline $\begin{array}{l}\text { Total Aspek } \\
\text { KPS }\end{array}$ & 63,65 & 65,22 & 48,00 & 59,02 \\
\hline
\end{tabular}

Data rata-rata aspek keterampilan proses sains kelas eksperimen dan kelas kontrol dapat ditampilkan dalam bentuk Gambar 2 sebagai berikut.

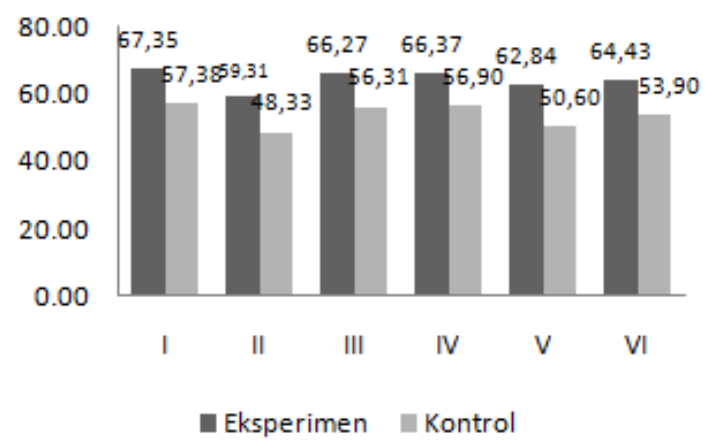

Gambar 2. Diagram Aspek Keterampilan Proses Sains Berdasarkan Model Pembelajaran

\section{Pengaruh Model Pembelajaran Terhadap Keterampilan Proses Sains Peserta Didik}

Berdasarkan hasil uji coba hipotesis keterampilan proses sains menyatakan ada pengaruh yang signifikan keterampilan proses sains peserta didik yang mengikuti model pembelajaran inkuiri terbimbing model pembelajaran konvensional Hal ini menunjukkan bahwa peserta didik yang mendapatkan pembelajaran dengan model pembelajaran inkuiri terbimbing secara keseluruhan menunjukkan keterampilan poses sainsnya lebih baik dibandingkan dengan peserta didik yang mendapatkan pembelajaran dengan model pembelajaran konvensional.
Tingginya perolehan nilai rata-rata kelas eksperimen disebabkan oleh model pembelajaran inkuiri terbimbing mengarahkan peserta didik pada berbagai aktifitas seperti mangamati, merumuskan, masalah dan hipotesis, mengajukan pertanyaan, merencanakan percobaaan, menggunakan alat/bahan percobaan, dan mengkomunikasikan.Hal ini sejalan dengan Jufri (2013), yang menyatakan bahwa salah satu karekteristik khas dari kegiatan inkuiri dalam bidang sains adalah pemberian peluang bagi peserta didik untuk berlatih merumuskan masalah dan hipotesis, merancang eksperimen, menginterprestasi data dan berlatih mengkomunikasikan hasil kegiatan belajarnya. Hal ini juga dikemukakan Miller, et al, (2013) proses inkuiri melibatkan seluruh aktivitas saintis untuk memperoleh informasi seperti berhipotesis, meramalkan, membaca, merencanakan dan melaksanakan eksperimen serta bekerjasama dengan saintis lainnya.

\section{Pengaruh Pengetahuan Awal terhadap Keterampilan Proses Sains Peserta Didik}

Hasil analisis data menunjukkan bahwa ada pengaruh keterampilan proses sains peserta didik yang memiliki pengetahuan awal tinggi dengan pengetahuan yang memiliki pengetahuan awal rendah. Untuk memperkuat hasil penelitian ini, maka dilakukan uji pengaruh pengetahuan awal (tinggi dan rendah) terhadap 5 aspek keterampilan proses sains. Pengujian hipotesis terhadap 5 aspek keterampilan proses sains menggunakan anakova dan Mann-Whitney karena ada 2 aspek yang tidak memenuhi uji prasyarat sehingga dilakukan dengan pengujian Mann-Whitney. Hasil pengujian hipotesis terhadap aspek mengamati, mengajukan pertanyaan, merencanakan percobaan, menggunkan alat/bahan percobaan dan mengkomunikasi menyatakan bahwa tidak 
ada perbedaan aspek keterampilan proses sains antara peserta didik yang memiliki pengetahuan awal tinggi dan peserta didik yang memiliki pengetahuan awal rendah. Hal ini menunjukkan bahwa pengetahuan awal memberi pengaruh terhadap keterampilan proses sains peserta didik.Pengetahuan awal mempengaruhi keberhasilan peserta didik memberikan interpretasi terhadap apa yang diamati. Pengetahuan awal peserta didik akan membantu mengenali fenomena-fenomena yang diamati dalam kegiatan demonstrasi maupun eksperimen. Miller, et al, (2013), menyatakan bahwa pengetahuan awal peserta didik akan menentukan keberhasilannya dalam melakukan observasi. Peserta didik akan mengaitkan hasil observasi denganpengetahuan yang sudah dimiliki. Penguasaankonsep peserta didik terbentuk sebagai hasil perpaduan antara hasil pengamatan dengan pengetahuan awal tersebut.Peserta didik dengan pengetahuan awal tinggi lebih mampu menyelesaikan fase-fase pembelajaranmaupun tujuan pembelajaran. Sehingga dapat dikatakan bahwa peserta didik kelas eksperimen memiliki keterampilan proses sains yang baik (Muammar, et al, 2015).

Pernyataan diatas sejalan dengan hasil penelitian yang dilakukan Basuki (2015), yang menyatakan bahwa ada pengaruh pengetahuan awal peserta didik terhadap keterampilan proses sains pada peserta didik kelas X SMAN 3 Mataram.

\section{Interaksi Model Pembelajaran dan Pengetahuan Awal Terhadap} Keterampilan Proses Sains Peserta Didik

Hasil uji hipotesis menunjukkan tidak ada interaksi antara model pembelajaran (Inkuiri terbimbing dan konvensional) dan pengetahuan awal (tinggi dan rendah) terhadap keterampilan proses sains peserta didik. Hal ini dapat ditampilkan dalam bentuk gambar interaksi seperti pada gambar 3 yang menunjukkan bahwa kedua garis yang mewakili pengetahuan awal peserta didik tidak bersilangan. Pernyataan diatas sejalan dengan yang diungkapkan oleh Basuki (2015), yang menyatakan bahwa garis yang mewakili perlakuan alat peraga APKEMIT dan non APKEMIT tidak terjadi perpotongan, maka dapat dikatakan tidak terjadi interaksiantara penggunaan alat peraga dan pengetahuan awal.

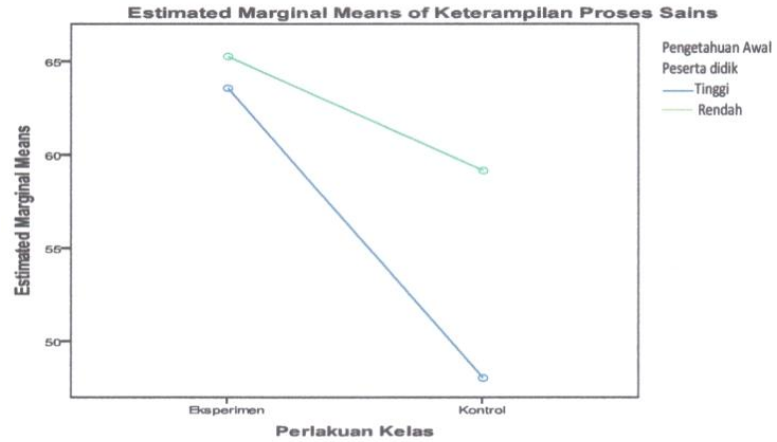

Gambar 3. Interaksi Model Pembelajaran dan Pengetahuan Awal Peserta Didik Terhadap Keterampilan Proses Sains

Gambar 3 di atas terlihat peserta didik yang memiliki pengetahuan awal tinggi yang mendapatkan perlakuan dengan model pembelajaran inkuiri terbimbing (kelas eksperimen) memiliki keterampilan proses sains lebih tinggi daripada peserta didik yang memiliki pengetahuan awal tinggi yang mendapat perlakuan dengan model pebelajaran konvensional (kelas kontrol). Demikian pula dengan peserta didik yang memiliki pengetahuan awal rendah pada kelas eksperimen memiliki keterampilan proses sains lebih tinggi daripada peserta didik yang memiliki pengetahuan awal rendah pada kelas kontrol.

\section{Pengaruh Model Pembelajaran terhadap Penguasaan Konsep Sains Peserta Didik}

Tes awal (pretest) penguasaan konsep yang diberikan sebelum proses pembelajaran kepada peserta didik menunjukkan bahwa peserta didik kelas 
eksperimen dan peserta didik kelas kontrol memiliki tingkat penguasaan konsep awal yang sama. Hal ini dapat ditunjukkan dengan melihat nilai rata-rata pada kelas eksperimen dan kelas kontrol. Setelah diberikan perlakuan yang sedikit berbeda pada kelas eksperimen mendapatkan perlakuan menggunakan model pembelajaran inkuiri terbimbing dan kelas kontrol mendapatkan perlakuan menggunakan model pembelajaran konvensional, tes akhir (postest) menggunakan soal yang sama dengan tes awal (pretest) diberikan kembali kepada peserta didik sehingga menunjukkan peningkatan yang berbeda dari nilai pretest dan postest antara kelas eksperimen dan kelas kontrol.

Hasil uji hipotesis penguasaan konsep sains menyatakan ada pengaruh yang signifikan penguasaan konsep sains peserta didik yang mengikuti model pembelajaran inkuiri terbimbing dengan model pembelajaran konvensional. Hal ini menunjukkan bahwa peserta didik yang mendapatkan pembelajaran dengan model pembelajaran inkuiri terbimbing secara keseluruhan menunjukkan penguasaan konsep sainsnya lebih baik dibandigkan dengan peserta didik yang mendapatkan pembelajaran dengan model pembelajaran konvensional. Hal ini sejalan dengan hasil penelitian Budiada (2012), yang menyatakan bahwa melalui penerapan pembelajaran inkuiri terbimbing, peserta didik akan menggali dan menemukan sendiri konsepkonsep yang terkait dengan materi pelajaran. Penemuan konsep melalui menemukan sendiri akan menjadikan belajar peserta didik lebih bermakna (meaningful learning), kebermaknaan dalam belajar akan berdampak pada daya ingat dan pemahaman peserta didik terhadap konsep-konsep yang lebih kuat sehingga akan berdampak positip terhadap hasil belajar. Selanjutnya Sukiman \& Jufri (2013) menyatakan bahwa kegiatan pembelajaran dengan menggunakan
Pembelajaran Sains Berbasis Inkuiri (PSBI) dapat membantu peserta didik untuk mengembangkan kompetensi yang berkaitan dengan berbagai indikator hasil belajar. Semakin banyak keterlibatan peserta didik akan semakin tinggi pula hasil belajar kognitifnya.

\section{Pengaruh Pengetahuan Awal terhadap Penguasaan Konsep Sains Peserta Didik}

Hasil analisis data menunjukkan bahwa tidak ada perbedaan penguasaan konsep sains peserta didik yang memiliki pengetahuan awal tinggi dengan peserta didik yang memiliki pengetahuan awal rendah. Hal ini menunjukkan bahwa pengetahuan awal tidak memberi pengaruh terhadap penguasaan konsep sains peserta didik. Pernyataan diatas sejalan dengan penelitian yang dilakukan Syaifuddin (2013), yang menyatakan bahwa peserta didik dengan kategori pengetahuan awal tinggi memiliki prestasi belajar yang sama dengan peserta didik yang memiliki pengetahuan awal sedang maupun rendah. Akan tetapi mengacu kepda penelitian yang dilakukan Effendi (2016), bahwa terdapat perbedaan penguasaan konsep antara siswa yang memiliki pengetahuan awal tinggi dan rendah. Penguasaan konsep peserta didik yang memiliki pengetahuan awal tinggi lebih tinggi dibandingkan dengan penguasaan konsep peserta didik yang memiliki pengetahuan awal rendah. Hal ini menunjukkan bahwa aspek pengetahuan awal peserta didik memberikan pengaruh terhadap penguasaan konsep peserta didik.

Pengetahuan awal adalah pengetahuan yang dimiliki seorang peserta didik sebelum peserta didik tersebut memperoleh pembelajaran kimia. Peserta didik yang memiliki jenjang pengetahuan awal tinggi akan memiliki tingkat kesiapan yang tinggi dalam menerima pelajaran. Peserta didik dalam kelompok ini memiliki keinginan belajar yang kuat serta berani 
mengutarakan pendapatnya jika mengalami kesulitan dalam mempelajari kimia, sehingga hasil prestasi belajar kimianya tinggi. Peserta didik yang memiliki jenjang pengetahuan awal rendah akan memiliki tingkat kesiapan menerima pelajaran yang rendah pula. Peserta didik yang demikian mempunyai keinginan belajar tidak sekuat peserta didik yang jenjang pengetahuan awalnya tinggi, sehingga dalam pembelajaran kimia bersikap pasif, akhirnya hasil prestasi belajar kimianya menjadi rendah.

\section{Interaksi Model Pembelajaran dan Pengetahuan Awal Terhadap Penguasaan Konsep Sains}

Hasil uji hipotesis menunjukkan ada interaksi antara model pembelajaran (Inkuiri terbimbing dan konvensional) dan pengetahuan awal peserta didik (tinggi dan rendah) terhadap penguasaan konsep sains peserta didik.

Hal ini sesuai dengan Gambar 4 yang menunjukkan bahwa kedua garis yang mewakili pengetahuan awal peserta didik bersilangan. Pernyataan di atas sejalan dengan yang diungkapkan oleh Gusmareta (2013), yang menyatakan bahwa terjadinya interaksi antara strategi pembelajaran dengan pengetahuan awal dalam mempengaruhi hasil belajar dapat ditunjukkan dengan gambaryang saling bersilangan antara strategi pembelajaran dengan pengetahuan awal.

Berdasarkan Gambar 4, peserta didik pada kelas eksperimen yang memiliki pengetahuan awal tinggi yang mendapatkan perlakuan dengan model pembelajaran inkuiri terbimbing memiliki keterampilan proses sains lebih tinggi daripada peserta didik pada kelas kontrol yang memiliki pengetahuan awal tinggi yang mendapat perlakuan dengan model pebelajaran konvensional. Demikian pula dengan peserta didik yang memiliki pengetahuan awal rendah pada kelas eksperimen memiliki keterampilan proses sains lebih tinggi daripada peserta didik yang memiliki pengetahuan awal rendah pada kelas kontrol (Santoso, 2014).

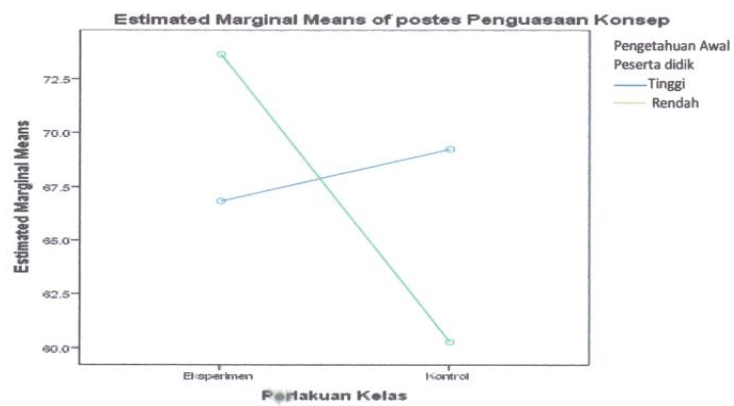

Gambar 4.Interaksi Model Pembelajaran dan Pengetahuan Awal Peserta Didik terhadap penguasaan konsep sains

Berdasarkan Gambar 4 di atas, pesertadidik pada kelas eksperimen yang berpengetahuan awal tinggi memiliki mean penguasaan konsep sains lebih rendah daripada peserta didik yang berpengetahuan awal rendah. Sedangkan peserta didik pada kelas kontrol yang berpengetahuan awal tinggi memiliki mean peguasaan konsep sains lebih tinggi daripada peserta didik berpengetahuan awal rendah. Hal ini menunjukkan bahwa penggunaan model pembelajaran sesuai dengan tingkat pengetahuan awal peserta didik, dalam hal ini peserta didik pada kelas eksperimen yang menggunakan model pembelajaran inkuiri terbimbing cenderung memberikan pengaruh penguasaan konsep lebih tinggi bagi peserta didik yang berpengetahuan awal rendah, sedangkan penggunaan model pembelajaran konvensional oleh peserta didik pada kelas kontrol cenderung memberikan pengaruh penguasaan konsep lebih tinggi bagi peserta didik yang berpengetahuan awal tinggi. Inilah yang menghasilkan terjadinya interaksi antara kedua faktor.

\section{PENUTUP}

Berdasarkan hasil penelitian dan pembahasan yang telah dilakukan maka 
dapat disimpulakan sebagai berikut: (1) Ada pengaruh model pembelajaran inkuiri terbimbing dan model pembelajaran konvensioanal terhadap keterampilan proses dan penguasaan konsep sains, (2) Tidak ada pengaruh pengetahuan awal terhadap keterampilan proses dan penguasaan konsep sains, (3) Tidak ada interaksi antara antara model pembelajaran (inkuiri terbimbing dan konvensional) dan pengetahuan awal (tinggi dan rendah) terhadap keterampilan proses sains, (4) Ada interaksi antara model pembelajaran (inkuiri terbimbing dan konvensional) dan pengetahuan awal (tinggi dan rendah) terhadap penguasaan konsep sains.

Perlu dilakukan penelitian dengan pokok bahasan lainnya untuk mengungkap hal lainnya yang berkaitan dengan hasil belajar. Dalam proses pelaksanaan pembelajaran guru hendaknya memperhatikan faktor-faktor yang mempengaruhi kegiatan pembelajaran seperti tingkat pengetahuan awal peserta didik yang berbeda. Kemudian perangkat pembelajaran hendaknya dipersiapkan dan dirancang dengan baik agar tujuan pembelajaran dapat tercapai dengan optimal dan perlu dilakukan penelitian tentang faktor-faktor lain yang berpengaruh terhadap keterampilan proses sains dan penguasaan konsep sains peserta didik, sehingga dapat menambah pengetahuan guru dalam upaya meningkatkan prestasi belajar peserta didik.

\section{REFERENSI}

Adodo, S. O. 2013. Effect of Mind-Mapping as a Self-Regulated Learning Strategy on Students'Achievement in Basic Science and Technology. Mediterranean Journal of Social Sciences. 6(1): 163-172.

Ambarsari, W. 2012. Penerapan Pembelajaran Inkuiri Terbimbing Terhadap Keterampilan Proses Sains
Dasar pada Pelajaran Biologi Siswa Kelas VIII SMP Negeri 7 Surakarta. Jurnal Pendidikan Biologi, 2(1), 117.

Arslan, A. 2014. Examination of the Effects of Model-Based Inquiry on Students' Outcomes: Scientific Process Skills and Conceptual Knowledge. Prosiding Social and Behavioral Sciences. 141, 1187 - 1191, Istanbul, Turki.

Azis, Y.M. 2013. The Effectiveness of Blended Learning, Prior Knowledge to The Understanding Conceptin Economics. Educational Research International, 2(2).

Azizirrahim, E., Sutrio, S., \& Gunawan, G. 2015. Penerapan Pendekatan Keterampilan Proses Sains dalam Model Pembelajaran Guided Discovery untuk Meningkatkan Hasil Belajar IPA Fisika pada Siswa Kelas VIIA SMPN 8 Mataram Tahun Ajaran 2015/2016. Jurnal Pendidikan Fisika dan Teknologi, 1(2), 272-275.

Basuki, B. 2015. Pengembangan Alat Peraga Kotak Energi Model Inkuiri Terbimbing (APKEMIT) dan Pengaruhnya Terhadap Keterampilan Proses Ilmiah dan Hasil Belajar Fisika Ditinjau Dari Kemampuan Awal Siswa. Jurnal Penelitian Pendidikan IPA. 1(1), 93102.

Bell, L., Smentana, L., \& Binns, I. 2005. Simplifying Inquiry Instruction Assessing The Inquiry Level of Classroom Activities. Diakses melalui: https://www. mun.ca/educ/ undergrad/ scied/ files/ bell_simplifying inquiry_2005. pdf. Tanggal 10 Maret 2016

Budiada. 2012. Pengaruh Penerapan Model Pembelajaran Inkuiri Terbimbing Berbasis Asesmen Portofolio Terhadap Hasil Belajar Kimia Siswa Kelas X Ditinjau Dari Adversity Quotient. Jurnal Penelitian program Pasca Sarjana Undiksha. 1(1). 
Effendi, M. 2016. Pengaruh Model Pembelajaran ECIRR Terhadap Penguasaan Konsep Fisika Pada Siswa SMK. Jurnal Pendidikan Sains, 4(3), 113-121.

Gusmareta, Y. 2013. Pengaruh Strategi Pembelajaran dan Pengetahuan Awal Terhadap Hasil Belajar Konstruksi Bangunan dan Menggambar 1 Mahasiswa Jurnal Tesis.

Jannah. 2015. Pengaruh Model Pembelajaran Kooperatif Dengan Pendekatan Problem Posing ditinjau dari Pengetahuan Awal terhadap Kemampuan Pemecahan Masalah Fisika Siswa SMK. Jurnal Pendidikan Fisika dan Teknologi, 1(4), 256-263.

Jufri, A. W. 2013. Belajar dan Pembelajaran Sains. Mataram: Arga Puji Press.

Kemendikbud. 2013. Modul Pelatihan Implementasi Kurikulum 2013. Badan Pengembangan Sumber Daya Manusia Pendidikan dan Kebudayaan dan Penjaminan Mutu Pendidikan.

Miller, K., Lasry, N., Chu, K., \& Mazur, E. 2013. Role of Physics Lecture Demonstrations in Conceptual Learning. Phyisical Review Special Topic-Physics Education Research, 9(2), 1-5.

Muamar, H., Hardjono, A., Gunawan, G. 2015. Pengaruh Model Pembelajaran Assure dan Pengetahuan Awal Terhadap Hasil Belajar IPA-Fisika Siswa Kelas VIII SMPN 22 Mataram. Jurnal Pendidikan Fisika dan Teknologi, 1(3), 166-172.

Rustaman N.Y., 2005. Strategi Belajar Mengajar Biologi. Malang: UM Press.

Sanjaya, W. 2012. Strategi Pembelajaran Berorientasi Standar Proses Pendidikan. Jakarta: Kencana Prenada Media Group.
Santoso, S. 2014. Pengolah Data Statistik di Era Informasi. Jakarta: Elex Media Komputindo.

Sugiyono. 2013. Metode Penelitian Pendekatan Kuantitatif, Kualitatif, dan $R \& D$. Bandung: Alfabeta Bandung.

Syaifudin, M. W. 2013. Eksperimentasi Model Pembelajaran Kooperatif Tipe Teams Assisted Individualization (TAI) Pada Pokok Bahasan Relasi dan Fungsi Ditinjau Dari Kemampuan Awal Siswa. MAGISTRA, 25(83), 11.

Tangkas. 2012. Pengaruh Implementasi Model Pembelajaran Inkuiri Terbimbing Terhadap Kemampuan Pemahaman Konsep dan Keterampilan Proses Sains Siswa Kelas X SMAN 3 Amlapura. Jurnal Tesis, 1(1).

Wood, K. C., Smith, H., \& Grossniklaus, D. 2011. Piaget's Stages of Cognitive Development. Departement. Departement of Educational Pshychology and Instructional Technology, University of Georgia. Diakses melalui: http://www.Saylor.Org/site/wpconte nt/uploads/2011/07/psych4065.3.2.pdf, tanggal 23 Januari 2016.

Yarden, H., \& Yarden, A. 2010. Learning Using Dynamic and Static Visualizations: Students' Comprehension, Prior Knowledge and ConceptualStatus of a Biotechnological Method. Res Science Education, 40: 375-402. 